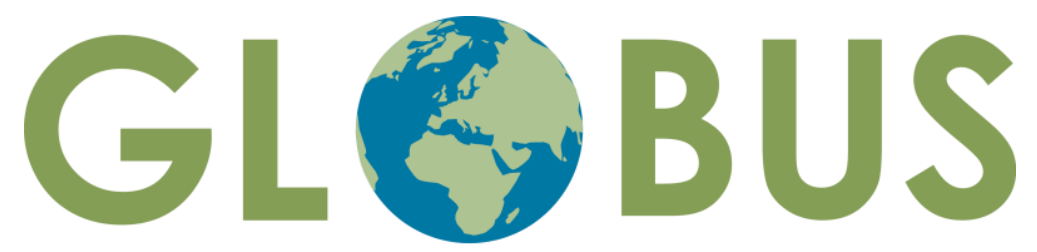

Reconsidering European Contributions to Global Justice

\title{
The Future of EU Development Policy Post-2020
}

Amelia Hadfield and Simon Lightfoot

GLOBUS Research Papers

01/2020 - January 2020 
Amelia Hadfield and Simon Lightfoot

The Future of EU Development Policy post-2020

GLOBUS Research Paper 1/2020

January 2020

(C) Amelia Hadfield and Simon Lightfoot

GLOBUS Research Papers (online) | ISSN: 2535-2504

http://www.globus.uio.no/publications/globus-research-papers/

Amelia Hadfield is Professor of European and International Relations and Head of the Department of Politics at the University of Surrey

Simon Lightfoot is Professor of Politics at the University of Leeds and co-convenor of the EADI working group on the EU as a development actor.

Reconsidering European Contributions to Global Justice (GLOBUS) is a research project that critically examines the EU's contribution to global justice.

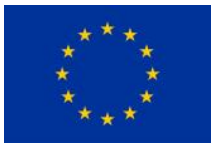

Funded by the European Union's Horizon 2020 programme. This work is the sole responsibility of the author. It does not reflect the opinion of the EU. The Research Executive Agency is not responsible for any use that may be made of the information it contains.

\section{www.globus.uio.no}

Twitter: @globus_h2020

f Facebook:@globus.h2020

Issued by:

ARENA Centre for European Studies

University of Oslo

P.O. Box 1143 Blindern

0318 Oslo, Norway

www.arena.uio.no

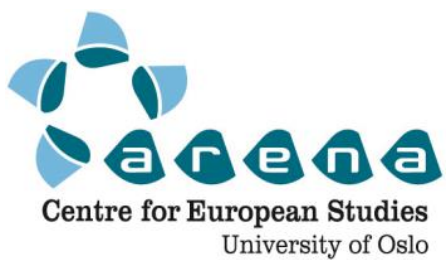




\section{Abstract}

Under the current proposals, the EU development cooperation budget would increase by 30\%. This paper explores how this potential increase is designed to assist the EU in consolidating its international identity in line with the aims of the Global Strategy (EUGS) by better aligning the money in the development budget to the global ambitions of the EU. This has reignited concerns that this represents further politicisation of the development activities of the EU beyond the Treaty commitment to poverty reduction and once again highlights the tension between development goals and broader strategic goals. This paper explores this tension between development and strategic goals in what is clearly a moving target area. Comparing how the vision for EU development policy has evolved between the 2006 and 2017 Consensus' on Development provides the context for a comparison to broader vision for external action set out in the EU's Global Strategy. The paper then explores the proposed budget reforms in light of this comparison highlighting the implications for the EU as a development actor. It shows how discussions around the size of the EU budget coincide with Brexit and the renegotiation of the EU's relationship with a key group of developing countries, the ACP. It shows that the future negotiations will focus on the overall amount of the EU development budget, how the budget will be used and where - decisions that will shine a light onto the priorities of the EU as a development actor.

\section{Keywords}

Development policy, European Consensus on Development, European Union, external action, Multiannual Financial Framework.

Research for this paper has received funding from the European Union's Horizon 2020 research and innovation programme under grant agreement no. 693609 (GLOBUS). 


\section{Introduction ${ }^{1}$}

The European Union (EU)'s draft Multiannual Financial Framework (MFF) for 202127 is currently under negotiation. If approved, the EU's development cooperation budget would increase by 30\% despite Brexit. The discussions around reforms to the budget are part of the realignment of foreign policy tools that assists the EU in consolidating its international identity in line with the aims of the Global Strategy (EUGS). Over the years we have seen a shift in the relationship between development and wider foreign policy concerns from a 'comprehensive approach' towards the 'integrated approach' set out in the EUGS (Faleg 2018). The 'comprehensive approach' started to ensure the EU operated in an increasingly complex foreign policy sphere in a more joined-up fashion, avoiding duplication and extra costs. The integrated approach takes this to the next level moving from process to a more systematic approach (see Faleg 2018). Moving towards an integrated approach involves more than semantics, and so exploring how development cooperation is framed in the MFF will represent a litmus test for the concrete implementation of the EUGS as the EU aims to 'distil a common vision into concrete plans' (Di Ciommo et al. 2017; Venturi 2019).

Development is clearly an area within which it is crucial that different actors and policy areas work in harmony with each other given the multi-faceted causes of poverty and under-development. This is complicated by the fact that development policy, like much of EU external action, is underpinned by norms (Orbie and Carbone 2016; Lightfoot and Kim 2018; Steingass 2019). The key to action thus far has been designing the most effective combination of policy tools to deploy in key theatres and sectors helping the EU become a more effective development actor (see Ehrhart and Petretto 2014: 180; Keijzer and Verschaeve 2018). The current plan is to follow this with a better alignment of the money in the development budget to the global ambitions of the EU.

There is a concern that this would represent further politicisation of the development activities of the EU. For example, there is a treaty commitment to poverty reduction which some critics fear is vulnerable to broader strategic concerns, with the EUGS explicitly stating that '[d]evelopment policy also needs to become more flexible and aligned with our strategic priorities' (EEAS 2016). The tension between development goals and broader strategic goals is a long-standing one in reforms of EU development cooperation (Carbone 2007).

The aim of this paper is to explore this perceived tension between development and strategic goals in what is clearly a moving target area. After a brief appraisal of the

\footnotetext{
${ }^{1}$ An earlier version of this paper was presented at the GLOBUS workshop 'The EU's trade and development policies in a changing global environment' on 14-15 March 2019. We would like to thank the GLOBUS project for the invitation to both attend the workshop and to publish this working paper. The paper builds upon ideas first surfaced in Hadfield and Lightfoot 2019. We would also like to thank Helene Sjursen, Johanne Døhlie Saltnes and Niels Keijzer for their comments on the earlier draft. Any errors remain our own.
} 
objectives of EU development policy, the paper first compares two documents that set out the vision for EU development policy; the 2006 Consensus and the 2017 Consensus on Development. We identify any changes between the two documents and what this means for the EU's future definition of and ambitions for development policy. Next, we compare the development goals of the EU with those set out in the EUGS and specifically the proposed reforms to the MFF. Finally, the paper will briefly explore the positions of the main actors (the Commission/EEAS, the Parliament and the member states) and offer some conclusions as to where the sources of agreement and tension will occur.

\section{EU Development Policy: Background}

In material terms, the EU is the world's largest donor of Official Development Assistance (ODA), providing over 50 per cent of global ODA, equating to over $€ 10$ billion in 2016. The sheer reach of EU assistance as well as its increasingly focused nature in terms of tools and instruments effectively equips the Union with leverage to 'use development cooperation to effect changes within third countries that parallel its world-view and foreign policy objectives' (Keukeleire and Delreux 2014: 211). EU ODA is distributed both geographically, i.e. focused on specific countries or regions, and thematically. The themes reflect EU priorities and norms and cover issues such as gender equality (e.g. promoting good practices in public and private sectors in sub-Saharan states like Zambia to strengthen gender mainstreaming), human rights and improved good governance more broadly, as well as newer features like migration (e.g. via capacity-building programmes tackling migration in the Horn of Africa) (European Commission 2017). This discussion highlights once again that all EU external relations have normative dimensions (see Sjursen 2006 for a fuller discussion of the normative aspects of EU external policy).

The Lisbon Treaty sets out that development policy is a shared parallel competence meaning that the member states maintain their own bilateral aid programmes alongside the EU's own long-standing multilateral development structure. It also states that EU development cooperation policy shall have as its primary objective the reduction and, in the long term, the eradication of poverty. Importantly, the Treaty sets out that the objectives of development cooperation need to be incorporated in other policies the EU implements which are likely to affect developing countries. The three principles that direct EU development policy are as follows: coherence of EU policy in and of itself (i.e. horizontal consistency); coordination between EU and its member states in facilitating non-duplicatory funding (i.e. vertical consistency), and complementarity between EU policies and programmes and those of its member states (i.e. intrinsic to the shared nature of the development competences) (see Orbie and Lightfoot 2017). The relationship between the member states and the EU as well as the relationships between the member states (see Krüger and Steingass 2019) are the key relationships in this policy sphere. 
In terms of the priorities of EU development policies, it has historically focused on the ACP (African, Caribbean and Pacific) countries (largely former UK and French colonies). This relationship formed the backbone of EU development policy under the oversight of DG Development. The most recent treaty underpinning the relationship, the Cotonou Partnership Agreement, covers relations between the EU and 70 ACP states in the areas of trade, political dialogue, and the role of norms and principles as part of the conditional aid framework. Cotonou has been both contentious in its negotiation and uneven in its implementation, with critics highlighting the asymmetrical nature of the relationship between the EU and the partner states (Bararinde 2019). The other key set of relationships within the field of development were with the Neighbourhood countries of North Africa and Eastern Europe under the oversight of the Directorate-General for European Neighbourhood Policy and Enlargement Negotiations (DG NEAR). The geographical division in development policy has been identified as preventing effective action in the development policy space, in part because the money was also connected to different Commission DGs (as we will show later). These tensions were reinforced by the different competences ascribed to the Commission and the member states according to which legal area the issue falls under. The complexity meant that in 2005 the Commission and the member states came together to agree the European consensus on development, the aim of which was to try and improve the delivery of aid by the EU and the member states (Carbone 2007).

\section{A tale of two consensus(es): 2006-2017}

The 2006 European Consensus on Development was premised on tackling poverty, against the explicit backdrop of the UN Millennium Development Goals (MDGs). The objectives of the consensus was to ensure that both the EU institutions and the member states in their bilateral policies shared the same vision. The Consensus set out the primary goal of development policy as 'the eradication of poverty in the context of sustainable development, including pursuit of the Millennium Development Goals'. Rather than identifying development as a means to a broader end (e.g. soft power or global influence), the Consensus argues that development is a central goal by itself while sustainable development refers to a package that reforms both governments and communities alike, including good governance, human rights and political, economic, social and environmental issues' (European Commission 2006).

Set against a backdrop of protracted turf wars between the EU and the ACP states in defining the ownership and management of development goals, the Consensus suggests that the EU will work both top-down with the UN and major funders, and bottom-up with beneficiaries themselves. Enhanced 'policy coherence' should therefore arise, with the EU taking greater account 'of the objectives of development cooperation in all policies that it implements which are likely to affect developing countries, and that these policies support development objectives'. In 2006 the EU widened the criteria for eligibility for aid beyond solely low-income countries (LICs) to also include middleincome countries (MICs) and consideration for regions which may yield more by way 
of 'comparative advantages and can add most value to the fight against poverty'. This shows that alongside the poverty reduction rhetoric, there was a growing connection between development policy and broader foreign policy concerns within the Consensus (see Carbone 2013; Henökl and Keijzer 2016).

A decade later, in 2017, the European Consensus on Development was updated in light of a changed global environment, further linking development policy to broader strategic and foreign policy concerns. The major change is the placement of the 2017 Consensus as 'the cornerstone of the EU's development policy'. Development also forms the centrepiece for the EU's Global Europe Strategy, including both its 2030 Agenda (covering sustainable development) and the 2016 Global Strategy (covering external action more broadly).

In stating that 'EU development policy also pursues the objectives of EU external action', laudably defined in development terms by the Lisbon Treaty, the 2017 Consensus is arguably a far clearer tool for EU external action than its predecessor. Consistency between all elements of external action requires coherent narrative engagement between the EU and its designated aid recipients, ensuring its own 'credibility, legitimacy, accountability, added value, influence and a positive impact on the world'. This is surely a valuable objective, particularly set against the risks of duplication and overlap, but the approach also signals the increasing importance of the 'optics' of giving in which ODA not only has to be given for the right reasons but also yield progressive results in relation to the EU's thematic approach to aid.

Combining poverty eradication with a range of other goals, chiefly that of sustainable development, means that the 2017 Consensus is broader thematically and geographically. The 2017 document also makes clear that international objectives ought also to reflect the EU's headline policies at home. For instance, in terms of 'the scale of financial investment needed to bring about universal access to safe and clean energy services', the consensus states that 'supporting Africa and the EU's neighbourhood in this energy transition will be part of the enabling framework for the EU's energy Union' (European Commission 2017: 24; see also Kuzemko and Hadfield 2016).

Migration is another good example. Not regarded as a key aspect of development in 2006, migration is in 2017 a key theme regarded as intimately attached to poverty, political instability, social insecurity and a primary economic driver. Tackling migration requires not only a broader approach to overlapping challenges but also a more facilitative approach to ensuring partners' cooperation. The 2017 Consensus provides a snapshot of 'the changing approach to global development' evident in the replacement of MDGs with SDGs (Sustainable Development Goals) and the 2030 Agenda. As such, sustainable development dominates as the overarching theme of the 2017 Consensus, reflecting a far wider approach to development in terms of long-term objectives, modes of implementation, methods of measurement, the preferred thematic vs. geographical balance to be struck, and identifiable bilateral and multilateral development partners (European Commission 2017). 
The 2017 Consensus effectively locates development as the seminal policy for the global community, and the EU itself as a leading policy provider, heightening the commitment to global governance outlined in the 2016 Global Strategy, while clarifying the trinity of objectives that underpin that strategy: engagement, responsibility and partnership. The 2017 Consensus thus makes clear that the EU's commitments, and their implementation, 'must be founded on a rules-based global order, with multilateralism as its key principle and the United Nations at its core' (European Commission 2017: 3). It is unclear whether the EU's preferred position is to lead from the front, partner in complementary fashion with the UN, or lead on a few chosen initiatives rather than the full spectrum of development goals, although the actions of the new Commission President Ursula Von der Leyen suggest a willingness to lead. However, two factors require clarification first before the geography of global development can be more clearly mapped out: the renegotiation of the ACP-EU relationship (Carbone 2019) and the impact of Brexit upon both the budget and the shape and objectives of EU development policy itself (Henökl 2017; Lightfoot et al. 2017). The fact that Brexit removes a vocal supporter of the ACP relationship at the same time as the Cotonou treaty comes up for re-negotiation may allow the EU the opportunity to reshape the objectives and reach of EU development policy, although core states such as France still wish to maintain the relationship (see Price 2016). Brexit is not the only contextual issue influencing EU development policy. The euro crisis and the rise of populist governments all work against development in that many governments wish to focus the limited spending at home (see Bodenstein et al. 2017; Beringer et al. 2019). Hence we need to explore whether the money in the EU budgets supports the EU's external norms.

\section{Competing norms in EU development policy}

Saltnes (2019: 536) has argued that we may see 'competing normative viewpoints on what an effective development policy post 2015 should entail'. A key area for competition is likely to be around the language associated with the commitment to 'poverty reduction' within the Treaties. It is clear that this normative competition will be at the heart of post-2020 policy discussions. Allwood (2019) argues that development policy is increasingly framed with reference to other priorities such as migration, security and climate change and this forces other issues such a gender off the radar, with a concern that poverty reduction will soon follow.

Poverty reduction has remained at the heart of EU development policy for many years moving from a focus on purely social and financial terms to more multifactorial explanations of the various causes and effects of poverty. The 2017 Consensus represents the latter; this gives the EU room to manoeuvre in designating a whole host of problems as effectively contributory to poverty, but it is possibly too ambiguous a definition understood as it is as 'social uplift rather than purely through primary aid or fiscal stimulus' (Interview, EU Official, Brussels, 5th May 2018). When the EUGS mentions the MFF, it refers explicitly to two areas of intervention: defence and development. When it comes to development, the EUGS states: 'Development policy will become more flexible and 
aligned with our strategic priorities' (EEAS 2016). The EUGS does reaffirm the collective commitment to achieve the 0.70 per cent target, although the EU collective ODA represented only 0.50 per cent in 2017. When the EUGS calls for development policies that are 'flexible and aligned with our strategic priorities', it mainly refers to strengthening their connections with other fields, such as migration and security.

The 2017 Consensus focuses on the 'quality and effectiveness' of the aid that the EU can provide, across rather more ambiguously defined areas such as good governance. Accordingly, the Comprehensive Approach that underpins foreign economic policies is plainly the preferred approach: 'when planning and implementing development cooperation, the EU and its Member States will pay particular attention to such interlinkages and to integrated actions that can create co-benefits and meet multiple objectives in a coherent way' (European Commission 2017: 8). The EUGS contains five vague commitments to poverty reduction through statements such as tackling the 'root causes of conflict and poverty' or allowing 'ever more people to escape poverty and live longer and freer lives' or 'we will fight poverty and inequality'. However, it does have a clear vision to deliver 'prosperity' via statements such as 'development funds should catalyse strategic investments through public-private partnerships, driving sustainable growth, job creation, and skills and technological transfers' (see EEAS 2016). This will simplify the Commission's external spending in line with the aim of the 2017 Development Consensus to provide 'simplification, and targeted and cooperative development' (European Commission 2017). The consensus sets development as the soft power centrepiece for the EU's Global Europe strategy, even going so far as to argue that it - as a strategy will 'contribute to the requirement of ensuring consistency between the different areas of EU external action, and between these areas and its other policies' (European Commission 2017). In turn, the MFF 2021-27 includes a proposal for a comprehensive financial instrument, which the European Commission sees as a main implementing tool for the consensus.

\section{Insights from the new MFF into norm debates? ${ }^{2}$}

Under the current MFF (2014 to 2020) the two key funding instruments reflect a geographic divide within EU external action. The European Development Fund (EDF) is the main funding source for ACP states, but this sits outside the formal EU frameworks, financed by direct contributions from all EU member states and covered by its own financial rules. The Development Cooperation Instrument is within the EU framework and covers programmes in Latin America, South Asia, North and South East Asia, Central Asia, Middle East and South Africa. The proposed re-organisation of the MFF is around four strategic Headings with the Commission's plan to create a single instrument under Heading 4 called 'the neighbourhood and international cooperation instrument', which will pool the resources of existing separate instruments, such as the European

${ }^{2}$ See Castillejo et al. (2018a) for an excellent overview of the prospects and challenges for EU development cooperation in the new MFF. 
Neighbourhood Instrument (ENI), European Development Fund (EDF), Development Cooperation Instrument (DCI), and European Initiative on Democracy and Human Rights (EIHDR) (European Commission 2018).

The Commission argument is that this will simplify external spending, avoid duplication and offer more flexibility, while maintaining that "poverty eradication remains the broad focus' and that 'the policies remain the same' (Castillejo et al. 2018b: 56). The proposal will also increase the amount of money available for external action, with one commentator arguing that 'development cooperation has emerged a winner' (Gavas 2018). Gavas argues that

at first glance, things are looking up for EU development spending with a proposed 26 percent increase from $€ 97$ billion (including the off-budget European Development Fund controlled by member states) to $€ 123$ billion over the sevenyear period, and an increased share of the EU budget from 6 percent to 10 percent. All this without the UK's current annual contribution of $€ 1.4$ billion to EU development spending. The increase comes from a variety of measures, including the scrapping of budget rebates and a reduction in agricultural subsidies and cohesion funds.

(Gavas 2018)

Within the overall budget, the new proposals see a 43 per cent increase in funding for the European Neighbourhood from $€ 15$ bn to $€ 22 b n$, funding that is 'ring fenced over the seven-year period'. This is a clear geographic indication of where the EU's interests lie in regards to targeted development. There is also a plan to increase funding to SubSaharan Africa by 23 per cent, with one of the factors behind this increase likely to be the EU's desire to tackle migration at the source, rather than respond to migration crises when they occur (Gavas 2018).

CONCORD (2018), a European NGO confederation for relief and development, agree that the proposals have a series of advantages, as they represent an opportunity to simplify the current architecture and to avoid duplication as well as ensuring greater coherence and complementarity between instruments. Given the possible political sensitivities around these discussions, the most recent peer review of the EU's plans by the OECD's Development Assistance Committee (DAC) did not swerve the issue and made a number of recommendations relating to the political context of the MFF negotiations. The peer review was carried out by development experts from Canada and Japan and is the standard OECD DAC method of reviewing the development cooperation of the DAC members. Their recommendations are a form of soft law and as such have political rather than legal weight. Of the many recommendations within the peer review, a major concern relates to the proposed changes to the development budget and their implications for the future of development cooperation, especially in light of the 2017 European Consensus on Development. The DAC review team saw a lack of operational guidance on how the 2017 Consensus's focus on poverty reduction and sustainable development will actually be kept up in light of the MFF negotiations. 
Such guidance, however, might be necessary to clarify 'how EU actors and member states will work coherently, particularly in focusing on the poorest countries and leaving no one behind' (OECD DAC 2018). This passage in the peer review chimes with criticisms that the EU's focus on security and migration would undermine its focus on partner countries' long-term development needs, particularly by increasingly designing development cooperation programmes with their impact on security and or migration in mind (Allwood 2019; Cardwell and Jančić 2019).

There is a concern that the one-pot-for-all approach would impact negatively on some key transversal issues like gender equality (see Allwood 2019). CONCORD (2018) is concerned that this proposal will not allow the EU to live up to its commitments on poverty eradication and sustainable development. In particular, they are concerned that issues like human rights or gender will no longer receive the attention and visibility they deserve and will be relegated as secondary priorities in a large instrument focused on forging partnerships with neighbouring and other countries to tackle EU migration, security and economic challenges (Allwood 2019). Even the name change is significant with Global Europe now becoming 'The Neighbourhood and the World', which leads to a sense of giving prominence to promoting security, stability and development in the EU's neighbourhood. This is a clear geographical expression of where the EU sees its real added value (Gavas 2018). There is a lack of clarity on the criteria for allocation of funds, which has prompted concerns that aid could be diverted towards the promotion of Development Finance Institutions (DFIs) and private investments. Budgetisation of the EDF has long been supported by the European Parliament and it is felt that this step would be an important one in the continued democratic oversight of EU development policy and the broader foreign policy (see Cardwell and Jančić 2019).

With this focus on the neighbourhood, there is also a fear that integrating the EDF into a single instrument will weaken the EU's relationship with the ACP states, especially the low-income countries. A large value share of EU ODA already goes to middle income countries in the EU's neighbourhood. From 2014-2016, the EU's top recipients of aid were Turkey, Morocco, Serbia and Tunisia, with internal member state interests guiding the allocation of funds (CONCORD 2018). By moving the EDF into the budget, given the primacy given to the EU's neighbourhood, there is a real risk of weakening not only the financial commitment towards the ACP countries, but also their privileged relationship with the EU (Gavas 2018). A specific concern is that once inside the budget, funds for the ACP states will become less visible and that the group will need to fight for resources. According to the peer review,

the risk of subordinating development objectives to broader security and migration concerns, then, remains a key challenge for the EU, as it does for other DAC members. In the EU's case, this challenge might be exacerbated by the proposed streamlining of instruments in the upcoming MFF if appropriate safeguards are not included.

(OECD DAC 2018) 
Saltnes is worth quoting at length on this:

The Commission's proposal to budgetise the EDF rests primarily on pragmatic arguments about efficiency and coherence. However, streamlining all EU development funds could harm long-term efforts to build a partnership with its counterparts in Africa, the Caribbean and the Pacific. [...] The ACP group has been an important critic of the budgetisation proposal. In a statement published on 30 May, the group stated that they were 'strongly in favour of maintaining the European Development Fund (EDF) as the main financial instrument in support of ACP-EU development cooperation'. They noted that 'one of its unique features is the fact that it is managed outside of the general EU budget' and that 'the EDF has fostered a particular culture that has made the ACP-EU partnership a unique development cooperation model'.

(Saltnes 2018, quoting ACP Group 2018)

Beyond the MFF, the DAC peer review highlights that the EU has shown leadership in its efforts towards reaching global agreements on sustainable development and climate change. It also praised its extensive use of budget support and variety of delivery instruments, which it notes enhances ownership and inclusiveness in partner countries. Finally, the review praised the joined efforts to build global citizenship across Europe. However, without the external affairs budget reflecting the wider policy priorities of development cooperation these positives may not be enough for the EU to maintain its position as an effective development actor.

There is likely to be very real competition between institutions and member states about the appropriate policy areas in which to make Global Europe truly effective. Member states vary in their geographical focus with a group including Denmark, France, Germany, Italy, the Netherlands and Spain tending to focus on Africa whilst others including Hungary, Poland, Finland and the Czech Republic are concerned about lack of funds for the Eastern Neighbourhood (Fallon 2019). There is also potential for further 'turf wars' between the Commission and the EEAS over development spending and even some possible tensions between the Commission's desire for flexibility and the European Parliament's desire for oversight which may prefer that funds be divided more transparently (European Parliamentary Research Service 2018; Cardwell and Jančić 2019). Interviews with Brussels-based decision-makers provide additional detail, a clear theme of which is the 'concern about duplication between the Global Europe's separate financial instruments', the 'limited scope within external action for dealing with crises, particularly in partner countries', as well as 'much greater clarity about the actual purpose of the EU's thematic and geographic instruments' in terms of improved development delivery (Interviews, Brussels, European Commission DG DEVCO, 4-6th May 2018). Key concerns highlighted by a development think tank include the budget's lack of flexibility in dealing with shocks or crises (including migratory pressures, security threats such as terrorist attacks, and climate change-induced events), as well as the need to make funds work better within its proximate and still volatile neighbourhood, while demonstrating astute investment internationally (Sherriff 2019). Brexit, of course, 
is likely to create further uncertainty, affecting as it does both the size and likely distribution of the budget.

Criticisms that the proposed budget plans signal a shift away from poverty to more strategic concerns have been countered in a reply to a blog post (Hadfield and Lightfoot 2019) by a respondent from the EEAS. He argued that

speculative concerns are difficult to address except through legal guarantees and effective action. The action will come later, during the programming and implementation phases of the 2021-27 budget, but the newly proposed legal framework under the NDICI (Neighbourhood, Development and International Cooperation Instrument) should already give some reassurances on top of the efficiency gains resulting from simplification and increased flexibility.

(van Damme 2019)

Further, he argued that this is done by the NDICI explicitly repeating the 2017 European Consensus on Development commitment to put 'the 2030 agenda and the SDGs at the heart of its development policy' along with 'minimal DACability of 92\%; minimal safeguarded allocation to Sub-Saharan Africa where a majority of LICs [...] are concentrated; minimal thematic allocations: $25 \%$ to meet climate objectives, $20 \%$ for social inclusion and human development'. There is also a pushback on security and migration with the argument being made that with an emphasis on

the root-causes of conflicts, irregular migration and forced displacement [which are] development and governance-related. The consolidation and support to democracy, rule of law and human rights therefore very explicitly remain overarching specific objectives of the new instrument in line with the Treaty objectives.

There is also an argument that

[w]ith the safeguards built into the legal framework, there is no reason to think that the 'streamlining of instruments' will exacerbate the perceived risks of subordination of the development objectives to broader external policy concerns which would undermine the achievement of those objectives and the achievement of the SDGs'.

(van Damme 2019)

Van Damme argues that 'the initial exchanges with the EU Member States and the European Parliament confirm the shared development focus and above guarantees are definitely not expected to be weakened during the final negotiations of the instrument, rather on the contrary'. In contrast, the ETTG argues 
that it is not clear whether the ambitious amount of the budget or the new single instrument will survive the negotiations. Financial resources for EU external action will, in large part, be determined by battles over other elements of the budget, notably agriculture and regional policy, as they have in the past. And the single instrument has yet to gain support from key Member States (MS) such as France and Poland.

(Castillejo et al. 2018a; this paper also provides an overview of all 28 member states positions for MFF)

Within the EU institutions there are key voices calling for the protection of the poverty reduction focus: Udo Bullman from the EP development committee sets out the broad EP position:

We want to preserve the autonomy of development policy - and to this end the European Treaties set poverty reduction as the primary objective. In order to pursue the Agenda 2030 consistently, however, we must also work even more intensively on interlinking trade, foreign and climate policy issues - to name just a few areas. This must not, however, mean that development cooperation becomes an appendix to other policy areas. It's important to prevent the instrumentalisation of development cooperation to safeguard European security interests and to restrict it to questions of migration management, for example.

(Bullman 2019)

Jutta Urpilainen, the commissioner elect for international partnerships, received a relatively easy ride during the confirmation process - according to one report it was 'smooth sailing' for her. The hearing gave some insight into the priorities going forward with the questions focused on security and migration, the role of the EP, relations with Africa and the role of the private sector. The most significant change is the replacement of the 'Development' Commissioner with a Commissioner for 'International Partnerships', and it is unclear whether this marks a rhetorical or substantive change, although it has been noted that the new title is less neo-colonial sounding (see Delputte et al. 2019). Also of note is the fact that the new Commission President's first international trip was to Africa. In doing so, von der Leyen is clearly setting out the geopolitical priorities for the new Commission.

\section{Conclusion}

EU development policy is increasingly 'situated between the bloc's normative ideals and global geopolitical realities within which it is embedded' (Beringer et al. 2019). So on the one hand we have this type of call: 
The way forward is to promote a strong EU development policy that is not subordinated to other strategic interests of the EU but is adamant when it comes to a few key principles. This relates to the long-term and multi-dimensional nature of sustainable development, the adherence to fundamental values as well as to key principles of aid effectiveness, and implies a move away from the EU's current damage control mode.

(Koch et al. 2018)

On the other we see a vision set out in von der Leyen's mission letter which appears to suggest that 'development' objectives are subordinated to European interests. The letter also argues that the EU expects 'value for money', that 'political, economic and investment opportunities in Africa' should be pursued, and that the EU should leverage aid for private investment. It also sets out an ambition of a 'geopolitical commission': the focus on 'countries of migration origin and transit', and the task to 'adapt bilateral funding to achieve our objectives on migration management' give an extra push to the instrumentalisation of EU aid for geopolitical and migration management purposes (Delputte et al. 2019).

The MFF debates will highlight these tensions over the coming months. As Venturi argues:

clearly, the MFF is not an easy test for EUGS implementation due to its complexity and to the need to balance domestic and foreign objectives. However, the EUGS has been internalized by the MFF debate, and it represents the document that will have, along with the Agenda 2030, the greatest impact on how the EU shapes external action policies under the new budget ceiling. Overall, it seems that the new MFF architecture can support the ambition of the EUGS. Additionally, the dedicated resources to external actions are slightly increased, notwithstanding the current budgetary difficulties related to Brexit. How development cooperation will be framed in the MFF will represent a test for the concrete implementation of the EUGS. The coming months will show whether this level of commitment can be maintained in the final MFF.

(Venturi 2019)

The complications though are myriad. Work undertaken by the Gavas (2018) suggests that a trinity of decisions need to be taken sequentially to intelligently gather together the implications for MFF size and use, the preferred post-Cotonou framework, and available UK development cooperation. These include deciding what the overall amount for EU development budget will be, how the budget will be used and how it will be managed (Gavas 2018). The various pressures on the Commission, from Brexit to the migration challenge, are contributing to the 'inward looking agenda' of the EU (Beringer et al 2019). Hence, we see an increased spotlight on how and where development funds are spent and by whom (Koch et al. 2018). Given the current political climate within the EU, Gavas's slightly sombre conclusion that the odds are stacked against the development-focused aspects of the MFF and the EUGS therefore appears 
to be the most realistic at present. The forces for development appear to be losing the battle for the normative direction of the EU's external policy to those who wish to see development supporting the strategic goals of the Union. 


\section{References}

ACP Group (2018) 'ACP Negotiating Mandate for a post-Cotonou Partnership Agreement with the European Union', ACP/oo/o11/18 FINAL, 30 May. Available at: http://www.acp.int/sites/acpsec.waw.be/files/acpdoc/public-documents/ACPooo $1118 \% 20 A C P$ Negotiating Mandate EN.pdf.

Allwood, G. (2019) 'Gender Equality in European Union Development Policy in Times of Crisis', Political Studies Review (online first), doi: 10.1177/1478929919863224. Available at: https://journals.sagepub.com/doi/full/10.1177/1478929919863224.

Bararinde, O. (2019) 'New Directions in EU-Africa Development Initiatives: Between Norms and Geopolitics in EU Development Policies' in S.L. Beringer, S. Maier and M. Thiel (eds) EU Development Policies: Between Norms and Geopolitics. New York: Palgrave Macmillan, pp. 111-134.

Beringer, S., S. Maier and M. Thiel (2019) 'Introduction' in S.L. Beringer, S. Maier and M. Thiel (eds) EU Development Policies: Between Norms and Geopolitics. New York: Palgrave Macmillan, pp. 1-16.

Bodenstein, T.J. Faust and M. Furness (2017) 'European Union Development Policy: Collective Action in Times of Global Transformation and Domestic Crisis', Development Policy Review 35(4): 441-453.

Bullman, U. (2019) 'I Believe that Combating Inequalities is Crucial', International Politics and Society, 24 September. Available at: https://www.ips-journal.eu/ regions/global/article/show/i-believe-that-combating-inequalities-is-crucial-3744/.

CONCORD (2018) CONCORD's Concerns and Redlines on the European Commission Proposal for a Single External Instrument. Brussels: CONCORD.

Carbone, M. (2007) The European Union and International Development: The Politics of Foreign Aid. London: Routledge.

Carbone, M. (2013) 'International Development and the European Union's External Policies: Changing Contexts, Problematic Nexuses, Contested Partnerships', Cambridge Review of International Affairs 26(3): 483-496.

Carbone, M. (2019) 'The Calm after the Storm: Plurilateral Challenges to the Post-2020 EU-ACP Partnership', JCMS Annual Review. Available at: https://onlinelibrary. wiley.com/doi/full/10.1111/jcms.12933.

Cardwell, P. and D. Jančić (2019) 'The European Parliament and Development Cooperation: Democratic Participation in the "Low Politics" of EU External Relations', Journal of European Integration 41(3): 365-381.

Castillejo, C., O. Chmiel, M. Di Ciommo, J. Jokela, N. Keijzer, E. Lundsgaarde, I. Olivié, A. Perez, S. Thijssen, J. Vaille, Z. Vegh and B. Venturi (2018a) 'Financing EU External Action: Understanding Member State Priorities', European Think Tanks Group Paper, December 2018. Available at: https://ettg.eu/2018/12/03/financing-euexternal-action-understanding-member-state-priorities/. 
Castillejo, C., M. Gavas, M. Di Ciommo, M.S. Monràs and N. Keijzer (2018b) 'The European Union's Next Multiannual Financial Framework: Prospects and Challenges for EU Development Cooperation', European Thinks Tank Group Paper, March 2018. Available at: https://ettg.eu/2018/03/16/the-european-unions-nextmultiannual-financial-framework-prospects-and-challenges-for-eu-developmentcooperation/.

Delputte, S., J. Orbie, and J. Schöneberg (2019) 'Tough Questions for New EU "Development" Commissioner', EU Observer, 1 October. Available at: https://euobserver.com/opinion/146119?utm source=euobs\&utm medium=email

Di Ciommo, M., A. Sherriff, and J. Bossuyt (2017) 'The Dynamics of EU Budget Negotiations for External Action: Towards a Single Instrument?', ECDPM Briefing Note 99. Available at: https://ecdpm.org/publications/dynamics-eu-budgetnegotiations-for-external-action-towards-single-instrument/.

EEAS (2016) 'Shared Vision, Common Action: A Stronger Europe. A Global Strategy for the European Union's Foreign and Security Policy', available at: http://eeas.europa.eu/archives/docs/top stories/pdf/eugs review web.pdf.

Ehrhart, H.-G., and K. Peretto (2014) 'Stabilizing Somalia: Can the EU’s Comprehensive Approach Work?’ European Security 23(2): 179-194.

European Commission (2006) The European Consensus on Development. Brussels: European Commission. Available at: https://ec.europa.eu/europeaid/sites/devco/ files/publication-the-european-consensus-on-development-200606 en.pdf.

European Commission (2017) The New European Consensus on Development: 'Our World, Our Dignity, Our Future'. Brussels. Available at: https://www.consilium. europa.eu/media/24011/european-consensus-for-development-sto9459en17.pdf.

European Commission (2018) Proposal for a Regulation of The European Parliament and of the Council Establishing the Neighbourhood, Development and International Cooperation Instrument $\{\operatorname{SEC}(2018) 310$ final $\}$ - $\{\mathrm{SWD}(2018) 337$ final $\}$.

European Parliamentary Research Service (2018) 'A new neighbourhood, development and international cooperation instrument: Proposal for a new regulation', EU Legislation in Progress 2021-2027, Briefing. Available at: http://www.europarl. europa.eu/RegData/etudes/BRIE/2018/628251/EPRS BRI(2018)628251 EN.pdf.

Fallon, N. (2019) 'Reconciling Foreign Policy and Development Priorities in the EU Budget (MFF 2021-2027)', Future of the EU27 Brief. Dublin: IIEA. Available at: https://www.iiea.com/wp-content/uploads/2019/og/NDICI-Paper-1.pdf.

Faleg, G. (2018) 'The EU: From Comprehensive to Integrated Approach', Global Affairs 4(2-3): 171-183.

Gavas, M. (2018) 'A Budget Fit for the Future? Breaking Down the EU's External Actions Proposals for the Next MFF', Center for Global Development Blog. Available at: https://www.cgdev.org/blog/budget-fit-future-breaking-down-eu-external-actionsproposals-next-mff.

Hadfield, A. and Lightfoot, S. (2019) 'Will the Future EU Budget Water Down the Consensus on Poverty Reduction and Sustainable Development', EADI Blog, 3 January. Available at: http://www.developmentresearch.eu/?p=283\#more-283.

Henökl, T. and N. Keijzer (2016) 'The Future of the European Consensus on Development', Briefing Paper No. 5/2016. Bonn: Deutsches Institut für Entwicklungspolitik (DIE). 
Henökl, T. (2017) 'How Brexit Affects EU External Action: The UK Legacy in European International Cooperation', Futures 97: 63-72.

Keukeleire, S. and T. Delreux (2014) The Foreign Policy of the EU. London: Red Globe Press.

Keijzer, N. and J. Verschaeve (2018) 'United in Diversity? Analysing Behaviour Expectations of the European Union as a Non-State Member of the OECD's Development Assistance Committee', Contemporary Politics 24(4): 379-397.

Koch, S., N. Keijzer, C. Hackenesch, J. Bergmann (2018) 'From Damage Control to Sustainable Development: European Development Policy under the Next EU Budget, Briefing Paper No. 7/2018. Bonn: Deutsches Institut für Entwicklungspolitik (DIE).

Krüger, L. and S. Steingass (2019) 'Policy Entrepreneurs in Brussels, Tied Hands at Home? EU Member States between Joint Policy-Making and Domestic Implementation in Development Co-operation', Journal of European Integration 41(4): 429-445.

Kuzemko C. and A. Hadfield (2016) 'Defining and Projecting EU Energy Policy' in J.M. Godzimirski (ed.) EU Leadership in Energy and Environmental Governance. Palgrave: London.

Lightfoot, S., E. Mawdsley, and B. Szent-Iványi (2017) 'Brexit and UK International Development Policy', The Political Quarterly 88(3): 517-524.

Lightfoot, S. and S. Kim (2018) 'The EU and the Negotiation of Global Development Norms: The Case of Aid Effectiveness', European Foreign Affairs Review 22(2): 159175 .

OECD DAC (2018) European Union: Peer Review. OECD: Paris.

Orbie, J. and M. Carbone (2016) 'The Europeanisation of Development Policy', European Politics and Society 17(1): 1-11.

Orbie, J., and S. Lightfoot (2017) 'Development: Shallow Europeanisation?' in A. Hadfield, I. Manners, and R. Whitman (eds) Foreign Policies of EU Member States. Continuity and Europeanisation. London and New York: Routledge.

Price, S. (2016) 'Brexit, Development Aid, and the Commonwealth', The Round Table 105(5): 499-507.

Saltnes, J.D. (2018) 'Why the Debate over the European Development Fund Is a Question of Politics', LSE Blog, 29 June. Available at: https://blogs.lse.ac.uk/ europpblog/2018/06/29/why-the-debate-over-the-european-development-fundis-a-question-of-politics/.

Saltnes, J.D. (2019) 'Resistance to EU Integration? Norm Collision in the Coordination of Development Aid', Journal of European Integration 41(4): 525-541.

Sherriff, A. (ed.) (2019) Investing in Europe's Global Role: The Must-Have Guide for the Negotiations of the Multiannual Financial Framework 2021-2027. Maastricht: ECDPM. Available at: https://ecdpm.org/wp-content/uploads/Europe-globalrole multiannual-financial-framework-2021-2027-must-have-guide-negotiationsECDPM-April-2019.pdf.

Sjursen, H. (2006) 'The EU as a 'Normative' Power: How Can This Be?', Journal of European Public Policy 13(2) 235-251. 
Steingass, S. (2019) 'Too Effective for Europe? The UK, Norm Advocacy and the Case of EU International Cooperation', Journal of Common Market Studies, early view. Available at: https://doi.org/10.1111/jcms.12927.

Van Damme, P. (2019) Reply to Hadfield and Lightfoot. Comment on blog post available at: http://www.developmentresearch.eu/?p=283.

Venturi, B. (2019) 'Toward the New Multiannual Financial Framework: Fuel for the EU Global Strategy and Development Cooperation?' EU Global Strategy Watch, 12. Foundation for European Progressive Studies (FEPS); Brussels. 


\section{GLOBUS Research Papers}

$1 / 2020$

Amelia Hadfield and Simon Lightfoot

The Future of EU Development Policy Post-2020

$6 / 2019$

Antonio de Aguira Patriota

Is the World Ready for Cooperative

Multipolarity?

$5 / 2019$

Ivor Sarakinsky

Recognition and Obligation

EU and South Africa Renewable

Energy Development Cooperation

$4 / 2019$

Samuel Brazys, Arya Pillai and Johanne

Døhlie Saltnes

EU Aid for Trade: Mitigating Global

Trade Injustices?

$3 / 2019$

Johanne Døhlie Saltnes

Global Justice and Aid Effectiveness

Reforms of the European Union's

Development Policy

2/2019

Franziskus von Lucke

Principled Pragmatism in Climate

Policy?

The EU and Changing Practices of

Climate Justice

$1 / 2019$

Cathrine Holst

Global Gender Justice

Distributive Justice or Participatory

Parity?
$14 / 2018$

Kholiswa Malindini and Odile Mackett

Trade Liberalisation and Female

Employment in Botswana and South

Africa

13/2018

Arrigo Pallotti

The European Union and Africa

Depoliticised Development and the

Elusive Quest for Democracy and

Security

$12 / 2018$

Sonia Lucarelli

The EU and the Crisis of Liberal Order At Home and Abroad

$11 / 2018$

Graham Finlay

The European Union as a Tolerant

Actor

$10 / 2018$

Matthieu Burnay and Marta Hermez

Towards Global Justice with Chinese

Characteristics

9/2018

Katie Verlin Laatikainen and Martin

Palouš

Contested Ground

The Campaign to Enhance the Status of the European Union in the UN

General Assembly

$8 / 2018$

Hayley Walker

Mutual Recognition in Global

Negotiations

The Case of the 2015 Paris Climate

Summit 
$7 / 2018$

Cathrine Holst

Promoting Global Justice when

Backlash Strikes

EU and UN Beijing +20

6/2018

Espen D.H. Olsen

Out but Still In

Norway's Approach to Migration and Asylum as a non-EU State

$5 / 2018$

Samuel Brazys and Krishna C.

Vadlamannati

Aid Curse with Chinese

Characteristics?

Chinese Development Flows and

Economic Reform

$4 / 2018$

Michela Ceccorulli

On Protection and Justice

The Proposals for Reform of the

Common European Asylum System

$3 / 2018$

Ben Tonra

The (In)Justices of Peacekeeping

EUFOR Tchad/RCA

$2 / 2018$

Nikola Tomić and Ben Tonra

The Pursuit of Justice through EU

Security Strategies

Sisyphus Redux?

$1 / 2018$

Alexa Zellentin

Different Angles on Climate Justice Insights from Non-domination and Mutual Recognition
$6 / 2017$

Mai'a K. Davis Cross

Europe's Foreign Policy and the

Nature of Secrecy

$5 / 2017$

Bettina Ahrens

The Solidarisation of International

Society

The EU in the Global Climate Change

Regime

$4 / 2017$

Mai'a K. Davis Cross

EU Institutions and the Drive for Peace

The Power of Ideas

3/2017

Kjartan Koch Mikalsen

Equal Sovereignty

On the Conditions of Global Political Justice

2/2017

Helene Sjursen

Global Justice and Foreign Policy

The Case of the European Union

$1 / 2017$

Franziskus von Lucke

O Justice, Where Art Thou?

Developing a New Take on Climate Justice

$1 / 2016$

Erik O. Eriksen

Three Conceptions of Global Political Justice 


\section{GLOBUS Research Papers}

The GLOBUS Research Papers are pre-print manuscripts on the EU's contribution to global justice as well as the wider question of Global Political Justice. The series is multidisciplinary, with a particular emphasis on the fields of international relations, political science, political theory, sociology and law.

\section{Reconsidering European Contributions to Global Justice - GLOBUS}

GLOBUS is a research project that critically examines the European Union's contribution to global justice. Challenges to global justice are multifaceted and what is just is contested. Combining normative and empirical research GLOBUS explores underlying political and structural obstacles to justice. Analyses of the EU's positions and policies are combined with in-depth studies of non-European perspectives on the practices of the EU. Particular attention is paid to the fields of migration, trade and development, cooperation and conflict, as well as climate change. GLOBUS' team of researchers covers the disciplines of politics, international relations, law, economics, sociology and political theory. The project is coordinated by ARENA Centre for European Studies at the University of Oslo and has partners in Brazil, China, Germany, India, Ireland, Italy and South Africa. It is funded by the Horizon 2020 Programme of the European Union for the period 1.6.2016 - 31.5.2020.

\section{Series Editor}

Helene Sjursen, ARENA Centre for European Studies, University of Oslo GLOBUS Coordinator

\section{Editorial Board}

Thomas Diez

Erik O. Eriksen

Sonia Lucarelli Pundy Pillay

Ben Tonra
Institute of Political Science, University of Tübingen ARENA Centre for European Studies, University of Oslo Department of Political and Social Sciences, University of Bologna Wits School of Governance, University of Witwatersrand School of Politics and International Relations, University College Dublin 